\title{
Stable isotopes changes in the adductor muscle of diseased bivalve Ruditapes philippinarum
}

\author{
Cécile Dang $^{1,2,{ }^{*}}$, X. de Montaudouin ${ }^{1,2}$, N. Savoye ${ }^{1,2}$, N. Caill-Milly ${ }^{3}$, P. Martinez ${ }^{4,5}$ and P. G. \\ Sauriau ${ }^{6}$ \\ ${ }^{1}$ Université de Bordeaux, UMR 5805, Station Marine d'Arcachon, 2 rue du Pr Jolyet, 33120 Arcachon, France \\ ${ }^{2}$ CNRS, UMR 5805, Station Marine d'Arcachon, 33120 Arcachon, France \\ ${ }^{3}$ IFREMER, Laboratoire Ressources Halieutiques Aquitaine, 64600 Anglet, France \\ ${ }^{4}$ Université de Bordeaux, UMR 5805, 33405 Talence, France \\ ${ }^{5}$ CNRS, UMR 5805, 33405 Talence, France \\ ${ }^{6}$ CNRS, LIENSs, Université de La Rochelle, 17000 La Rochelle, France
}

*: Corresponding author : C. Dang, Tel: + 335562239 36, Fax: + 335565493 83, email address : c.dang@epoc.u-bordeaux1.fr

\begin{abstract}
:
In this article, we show how a disease could bias stable isotope analyzes of trophic networks and propose a strategy in the choice of tissues to be analyzed. In the past few years, a new pathology (brown muscle disease or BMD) affecting the posterior adductor muscle of Ruditapes philippinarum has emerged in Arcachon Bay. BMD induces a necrosis of muscle tissues which become infused by conchiolin and hence calcified. As muscle of mollusks are often used for trophic food webs studies through stable isotopic analyzes, this work investigated the effect of BMD on carbon and nitrogen isotopic ratios of anterior and posterior adductor muscles of clams collected in February and August 2007. Infected clams displayed a lower condition index and a posterior adductor muscle $\delta^{13} \mathrm{C}$ enrichment of $1.2 \%$ in February and $0.7 \%$ in August. $\delta^{15} \mathrm{~N}$ of posterior muscles was however not affected by the disease. Anterior muscle of diseased clams remained healthy and displayed the same isotopic signature as both posterior and anterior muscular tissues of healthy clam. Acidification significantly depleted $\delta^{13} \mathrm{C}$ in posterior muscles of infected clams, suggesting calcification, contrary to anterior muscles of infected clam and to both muscles of healthy clams, where no effect was observed. An X-ray diffractometry analysis confirmed the presence of $\mathrm{CaCO}_{3}$ (aragonite). Trophic food web studies relying on stable isotope ratios should utilize only healthy animals or anterior adductor muscles when expertise in mollusk pathology is lacking.
\end{abstract}

Keywords: Clam - Ruditapes philippinarum - Stable isotopes - Adductor muscle - Disease Calcification 


\section{Introduction}

The Manila clam Ruditapes philippinarum (Adams \& Reeve, 1850) originates from Indo-Pacific waters and nowadays contributes to more than half of global yields of clams. Since 1930, Manila clam has been introduced with Pacific oyster (Crassostrea gigas) seed into different parts of the world, e.g. from the United States to Canada and to the Hawaiian islands (Flassch and Leborgne 1992). In Europe, R. philippinarum was primarily introduced into France for culture purposes in 1972 and later to England, Spain and Italy (Flassch and Leborgne 1992). Within a few years, the species established natural populations in most southern European countries and particularly along the French Atlantic coast. In Arcachon Bay (SW France), R. philippinarum was first introduced in 1980 as a commercially attractive species. It rapidly escaped from clam-growing areas and colonized intertidal sea-grass beds (Zostera noltii). Today, R. philippinarum undergoes intensive exploitation by local fishermen and has a relatively high economic value.

Since its introduction to France, $R$. philippinarum has endured several infectious pathologies such as the brown ring disease (BRD) caused by the bacterium Vibrio tapetis (Paillard 2004), perkinsosis induced by the protozoan Perkinsus sp. (Lassalle et al. 2007), and to a lesser extent, trematode infections (Lassalle et al. 2007). Recently, a presumptive viral pathology called the brown muscle disease (BMD) has occurred in Manila clam populations from localities of Arcachon Bay (Dang et al. 2008; Dang et al. In press). The anterior adductor muscle never exhibits macroscopic signs of the disease (Dang et al. 2008).

Stable isotope analyses (SIA) are widely used to investigate dietary pattern and trophic relationships in the marine environment (Peterson and Fry 1987). $\delta^{13} \mathrm{C}$ values help in identifying primary food sources assimilated by consumers (Fry and Sherr 1984) whereas $\delta^{15} \mathrm{~N}$ values allow determination of their trophic levels (DeNiro and Epstein 1981). SIA have also recently been used to characterize host-parasite systems and provide a means of exploring relationships between a host and its parasites (Deudero et al. 2002).

The objectives of this study were to investigate the effects of the brown muscle disease on the stable isotopic carbon and nitrogen ratios of adductor muscles, of Manila clams. Condition index and SIA are expected to provide complementary information on possible metabolic disturbances within muscles, as anterior and posterior adductor muscles of healthy and BMD-infected clams were comparatively analyzed by SIA. The idea was to compare stable isotopic signatures of infected muscle (posterior) with anterior muscle which never develops macroscopic signs of BMD in order to assess in what extent $\delta^{13} \mathrm{C}$ and $\delta^{15} \mathrm{~N}$ values are affected by the disease and could lead to shortcomings in term of trophic relationships interpretations. The possibility that muscle was calcified by the disease was also investigated in order to test the possibility to acidify tissues prior to SIA.

\section{Materials and methods}

Sampling strategy and clams treatment

Specimens of Ruditapes philippinarum were collected at Lanton, an intertidal area of Arcachon Bay, which is located on the southwestern Atlantic coast of France. Manila clams were then selected at different macroscopic stages of the brown muscle disease (BMD): healthy (Fig. 1a), intermediate and advanced (Fig. 1b) (Dang et al. 2008). At the intermediate stage, the striated part of the posterior adductor muscle was more severely infected than the smooth part. The adductor muscle attachment was reduced by the presence of brown spots which enlarged (initial calcification). The advanced stage of BMD 
displays a quasi-complete brown calcification of the striated muscle like the major part of the smooth muscle.

Ten healthy and ten diseased clams (30-36 mm shell length) were sampled in February 2007. Diseased clams were only collected in the intermediate stage of BMD. Posterior adductor muscles were dissected and freeze-dried for $48 \mathrm{~h}$. According to the preliminary results obtained in February, ten healthy and ten diseased clams of the same shell length were sampled at the same location in August 2007 and both anterior and posterior adductor muscles were analyzed. Infection was quantified in clams in advanced stages of BMD in August by the Final Disease Index (FDI) proposed by Dang et al. (2008) from 0 (no infection observed) to 4 (fully infected). Clams were opened, their FDI evaluated and their posterior and anterior muscles dissected, freeze-dried and weighed. Dry weights $(\mathrm{mg})$ of the remaining tissues together with dry weights of their shells $(\mathrm{g})$ were utilized for the calculation of the condition index $(\mathrm{Cl})$. The condition index is reported as $\mathrm{Cl}=$ dry flesh weight / dry shell weight.

Isotopic and elemental analysis

Samples of clam muscle tissues were ground to a homogeneous fine powder and $1 \mathrm{mg}$ was folded into tin cups (9-mm height, 5-mm diameter). Stable-isotope ratios measurements were performed on a Carlo Erba 2500 elemental analyzer in line with a VG Isoprime. The analytical precision was $0.2 \%$ for both $\delta^{13} \mathrm{C}$ and $\delta^{15} \mathrm{~N}$, estimated from several calibrated laboratory standards analyzed along with the samples. Replicates of February samples were performed to confirm the analytical reproducibility that was within $0.2 \%$. Stable isotopic ratios are reported as

$$
\begin{aligned}
& \delta^{A} X=\left[\left(R_{\text {sample }} / R_{r e f}\right)-1\right] \times 1000 \\
& w \delta X=\left(R_{\text {sample }} /-1\right) \times 1000
\end{aligned}
$$

where $\mathrm{A}$ is the atomic mass of the heavy stable isotope of the element $\mathrm{X}$, and $R_{\text {sample }}$ and $R_{\text {ref }}$ are the ratios of heavy to light isotope of sample and reference, respectively. References are atmospheric nitrogen for $\delta^{15} \mathrm{~N}$ and Vienna Pee Dee Belemnita (PDB) for $\delta^{13} \mathrm{C}$. Organic carbon and nitrogen contents were measured simultaneously with the stable isotopic ratios by integrating the voltage of the main ion beam (IRMS).

According to the extreme hardness of diseased posterior adductor muscles and following preliminary positive tests with $\mathrm{HCl}$, the presence of calcification and therefore inorganic carbon was expected to occur. In many ecological studies, it has been common practice to acidify samples to remove inorganic carbonates which are less negative in $\delta^{13} \mathrm{C}$ than other fractions (DeNiro and Epstein 1978).

To confirm this hypothesis and to exclusively evaluate the $\delta^{13} \mathrm{C}$ of organic carbon in muscle tissue, all February and August samples were decarbonated by acidification for a second carbon isotopic analysis: $1.3 \mathrm{mg}$ of powder was deposited into silver cups and acidified by adding $1 \mathrm{M} \mathrm{HCl}$ drop by drop until the cessation of bubbling. At last, $140 \mu \mathrm{L}$ was added and samples were left for $4 \mathrm{~h}$ in acid. Then, they were again dehydrated and freeze-dried for $48 \mathrm{~h}$. Both carbon isotope ratios and carbon contents were measured, as previously described.

Powder X-ray diffractometry (XRD)

Powder XRD is a convenient, non-destructive tool used to differentiate between multiple phases of materials, owing to the unique diffraction patterns produced from the crystallographic structures of each polymorph. Since the diffraction pattern of each crystalline form of a compound is unique, XRD is particularly suited for the analyses of solid mixtures. Moreover, the intensities of the peaks are unique to each phase and 
enable qualitative analyses. The analysis is then expected to confirm calcification of the diseased muscle and to determine which crystal is present. Powder remaining from the isotopic analyses of August posterior muscles was used. The ten healthy and the ten diseased samples were pooled in order to get enough healthy and diseased powder for the XRD analysis. Then, powder were placed in aluminium holders, pressed with a glass blade and exposed to CuKa radiation $(\mathrm{K} \alpha=1.5418 \AA$ ) in a wide-angle $\mathrm{X}$-ray powder diffractometer (Model, PANalytical X'pert MPD, Bragg-Brentano geometry). The angular range was $8.020^{\circ}$ to $79.980^{\circ}$ and the angular step size was $0.02^{\circ}$. Eventually, diffraction patterns of samples were elaborated and compared to diffraction patterns of known crystals using DIFFRACplus software in order to determinate which crystals, if any, were present in the samples.

\section{Statistical analyses}

Differences between diseased and healthy muscles were tested with analyses of variance and/or non-parametric test. Maximum type I error rates were set at $\alpha=0.05$. Homogeneity of variance was checked using Cochran test. Significant ANOVA results were followed by multiple comparisons using the conservative Tukey's HSD post-hoc test (Sokal and Rohlf 1981). When variances were not homogeneous, the non-parametric Mann-Whitney U test and Kruskal-Wallis test were used to assess differences between two and several groups of samples, respectively. Correlation between variables non-normally distributed was tested by the Spearman's rank correlation method. Statistical analysis was performed using Statistica software 7.1.

\section{Results}

\section{Condition index and final disease index}

Healthy and diseased adductor muscles can be easily distinguished (Fig. 1). Healthy clams displayed a significant higher condition index than infected clams $(p=0.007)$ with average values of $54.4 \pm 4.8$ ( \pm SE) and $34.4 \pm 4.5$, respectively. Final Disease Index (FDI) was calculated for each clam processed in August and FDI ranged between 8 and 16 for diseased clams. A significant negative correlation was found between FDI and the condition index $(r=-0.54, p=0.013, n=20)$.

Pre- acidification stable isotopes analyses

In February, $\delta^{13} \mathrm{C}$ and $\delta^{15} \mathrm{~N}$ values of the posterior adductor muscle of $R$. philippinarum ranged from $-17.5 \%$ o to $-16.6 \%$, and $8.8 \%$ o to $9.7 \%$ respectively for healthy clams whereas these ratios varied from $-16.2 \%$ o to $-14.1 \%$, and $8.5 \%$ to $9.5 \%$ respectively for diseased clams (Fig. 2a). $\delta^{13} \mathrm{C}$ values of infected clams exhibited a higher range than those of healthy clams $(2.1 \%$ vs $0.9 \%$ ). Muscles of diseased clams were significantly enriched in ${ }^{13} \mathrm{C}(\mathrm{p}=0.0002)$ by $1.2 \%$ on average $(-15.6 \%$ vs $-16.8 \%)$ compared to healthy clams (Fig. 2a, Table 1). No significant difference was noted in the $\delta^{15} \mathrm{~N}$ values between healthy and diseased clams $(8.9 \%$ vs $9.2 \%)(p=0.111)$. $\mathrm{C} / \mathrm{N}$ ratios in healthy animals ranged from 3.8 to 4.1 with a mean value of $3.9 \pm 0.02$ (Fig. 2b, Table 1). Conversely, diseased clams exhibited scattered values between 3.9 and 5.5 (mean $=4.4 \pm 0.16$ ) (Fig. 3b). Posterior muscles of BMD infected clams had significantly higher $\mathrm{C} / \mathrm{N}$ ratios than healthy bivalves $(p=0.001)$.

In August, both anterior and posterior muscles were analyzed. Due to seasonal variations, posterior adductor muscles of healthy clams in August were depleted in ${ }^{13} \mathrm{C}$ compared to February (-17.6\% vs -16.8\%) (Figs. 2a, 3a, Table 1). The dual plot of $\delta^{13} \mathrm{C}$ and $\delta^{15} \mathrm{~N}$ in August exhibited the same trends as in February with a higher range in $\delta^{13} \mathrm{C}$ for posterior 
muscles of diseased clams compared to those of healthy clams (2.4\% vs $0.6 \%$ ) combined with a ${ }^{13} \mathrm{C}$ enrichment $\left(0.7 \%\right.$ ) in diseased clams. $\delta^{13} \mathrm{C}$ and $\delta^{15} \mathrm{~N}$ values varied from $-17.9 \%$ to $-17.2 \%$, and $7.9 \%$ o to $9 \%$, respectively, for healthy clams and from $-17.9 \%$ o to $-15.6 \%$, and $7.8 \%$ to $8.4 \%$ respectively for infected clams (Fig. 3a). Mean values of carbon and nitrogen stable isotope signatures were $-17.6 \pm 0.05 \%$ and $8.6 \pm 0.05 \%$ respectively for healthy bivalves, $-16.8 \pm 0.25 \%$ and $8.1 \pm 0.07 \%$, respectively for diseased clams.

For anterior muscles, $\delta^{13} \mathrm{C}$ and $\delta^{15} \mathrm{~N}$ values ranged from $-17.8 \%$ o to $-17 \%$, and $8 \%$ o to $9.7 \%$ o with mean values averaging $-17.5 \pm 0.05 \%$ and $8.9 \pm 0.11 \%$ respectively for healthy clam, and ranged from $-17.8 \%$ o to $-17.1 \%$, and $8.7 \%$ to $9.9 \%$ with mean values of $-17.6 \pm$ $0.09 \%$ and $9.1 \pm 0.13 \%$ respectively for diseased clams. There was no significant difference in both $\delta^{13} \mathrm{C}$ and $\delta^{15} \mathrm{~N}$ values of anterior muscles between healthy and diseased clams ( $p=0.22$ and $p=0.39$, respectively). $\delta^{13} \mathrm{C}$ range was low and averaged $0.7 \%$ for both infected and no infected animals (Fig. 3a).

Posterior muscles of infected clams were significantly enriched in ${ }^{13} \mathrm{C}$ compared to anterior muscles of both healthy and infected clams and to posterior muscles of healthy bivalves ( $p=0.001$, Tukey Test, Fig. $3 a$, Fig. 4 ). $\delta^{15} \mathrm{~N}$ values of both infected and healthy clams anterior muscles were significantly different from those of both posterior muscles ( $p$ $<0.001$, Tukey Test, Fig. 4). $\delta^{15} \mathrm{~N}$ values of posterior muscles were not significantly different from those of anterior muscles in healthy clams in contrast to diseased clams ( $p$ $<0.001$, Tukey Test, Fig. 4).

$\mathrm{C} / \mathrm{N}$ ratios ranged from 4.3 to 4.9 and averaged $4.6 \pm 0.07$ for posterior infected muscles and ranged from 3.6 to 3.9 for anterior diseased muscles and both healthy muscles (Fig. $3 b) . C / N$ ratios were significantly higher for posterior muscles in infected clams compared to anterior muscles in infected clams and both muscles in healthy clams $(p<0.001)$.

FDI calculated for each clam processed in August varied between 8 and 16 with a high proportion of clams in class 16 . Significant positive rank correlations were found between FDI and both $\delta^{15} \mathrm{~N}$ and $\mathrm{C} / \mathrm{N}$ ratios $(r=-0.5, p=0.01$ and $r=0.9, p<0.001$, respectively, $n$ $=20)$. No significant correlation was observed between FDI and $\delta^{13} C(r=0.3, p=0.19, n$ $=20)$.

Post- acidification stable isotopes analyses

All clam samples from both February and August samples were analyzed for stable isotopes after acidification to remove inorganic carbon. No significant effect of the acidification process was noted for both muscles of healthy clams and for the anterior muscle of diseased clams ( $p>0.05$ ). In contrast, significant ${ }^{13} \mathrm{C}$ depletions of $0.8 \%$ o in February and 1.1\% in August were observed after acidification of the posterior muscle of diseased clams $(p=0.005)$ (Table 1$).{ }^{13} \mathrm{C}$ values of infected posterior muscles were $15.6 \%$ and $-16.8 \%$ before acidification and became $-16.4 \%$ and $-17.9 \%$ in February and August, respectively after acidification (Table 1). Acidification reduced the range in $\delta^{13} \mathrm{C}$ values of the posterior infected muscle, which became similar to the low variability observed in $\delta^{13} \mathrm{C}$ values of healthy clams (Table 1 ). However, the posterior adductor muscle after acidification remained significantly different $(p<0.05)$ from both healthy muscles and anterior muscle of diseased clams.

\section{X-ray diffractometry}

Apart from the occurrence of four peaks corresponding to aluminum of the holder, the XRD pattern of posterior adductor muscle of diseased and healthy clams greatly differed (Fig. 5). No mineral was detected within the healthy muscle sample. However, a bulge was noticed around $20^{\circ}$ angle (20) and was assumed as the sign of amorphous organic material. This bulge was not found in the XRD pattern of diseased clams, which contained numerous peaks of crystalline compounds such as halite $(\mathrm{NaCl})$ and aragonite $\left(\mathrm{CaCO}_{3}\right)$. Aragonite has an orthorhombic crystalline structure and was found in high concentration within the infected posterior muscles. 


\section{Discussion}

Brown Muscle Disease (BMD) significantly modifies the $\delta^{13} \mathrm{C}$ values of the posterior adductor muscle. Compared to healthy clams, the observed ${ }^{13} \mathrm{C}$ enrichment, i.e. $1.2 \%$ in February and $0.7 \%$ in August, is mainly but not exclusively due to the calcification by aragonite $\left(\mathrm{CaCO}_{3}\right)$. Indeed, after acidification, $\delta^{13} \mathrm{C}$ of diseased posterior muscles is closer, but remains slightly different from $\delta^{13} \mathrm{C}$ values of healthy muscles. Conversely, neither $\delta^{13} \mathrm{C}$ of anterior muscles, nor $\delta^{15} \mathrm{~N}$ of both anterior and posterior muscles are modified by BMD.

Standards errors (SE) of carbon isotopic ratios of posterior adductor muscle of Ruditapes philippinarum were 0.13 and $0.06 \%$ in February and August respectively (Table 1 ). This variability was similar to that observed in other bivalve species. In general, SE were lower than 0.15 with $\delta^{13} \mathrm{C} \pm$ SE of $-22.6 \pm 0.06 \%$ in Crassostrea gigas (Malet et al. 2007), -15.2 $\pm 0.03 \%$ in Pecten maximus (Lorrain et al. 2002), $-16.4 \pm 0.06 \%$ in Mytilus galloprovinciallis (Machás et al. 2003), -16.6 $\pm 0.08 \%$ in Ruditapes decussatus (Machás et al. 2003) and $-14.3 \pm 0.13$ in Cerastoderma edule (Page and Lastra 2003). Conversely, diseased posterior muscle of Manila clam exhibited higher variability with $\delta^{13} \mathrm{C} \pm \mathrm{SE}$ values of $-15.62 \pm 0.23 \%$ and $-16.80 \pm 0.25 \%$ in February and August respectively (Table 1 ), according to various level of calcification within muscles.

The inter-individual variability in $\delta^{13} \mathrm{C}$ in the present study was lower than $1 \%$ for posterior and anterior muscles of healthy clams and for anterior muscles of diseased clams. In contrast, this variability rose above $2 \%$ for diseased posterior muscles. This variability is very large compared to the usual trophic enrichment of $0.5-1 \%$ o that occurs with trophic level increase in food webs (DeNiro and Epstein 1978; McCutchan et al. 2003). Consequently, BMD could bias the interpretation of isotopic data in the context of trophic studies if BMD were not recognized prior tissue analyses. Indeed, the adductor muscle is commonly used in trophic studies of clams because of its long turnover rates compared to other tissues with fast turnover such as digestive glands and gonads (Kasai et al. 2004; Kanaya et al. 2005).

Even if BMD did not affect the isotopic signature of the anterior adductor muscle, the lower condition index of diseased clams compared to healthy clams suggests a general weakening of the animal. At this period of the year, the condition index of affected clams should be one and a half higher, like unaffected clams (Laruelle et al. 1994). The decrease of the condition index was in minor part due to the dry weigh of muscles and in major part due to a weight loss of the whole animal.

BMD induces a calcification of the adductor posterior muscle as revealed by X-ray diffractometry. The presence of aragonite and not calcite within the muscle in clams infected by BMD appears normal because of its inner position within the clam. It may indicate that the calcification is controlled by biogenic processes, i.e. protein matrix (Goulletquer et al. 1989), and immune response through enzyme activity (Jing et al. 2007).

The isotopic signature measured in infected clams corresponded with the cellular response of clam in respect to an infectious agent and not to the infectious agent, like in many other studies where the parasite could be analyzed separately from the tissue (Deudero et al. 2002). Thus, the observed shift in $\delta^{13} \mathrm{C}$ values actually reflects the metabolic consequences of the disease on the clam tissues and is thus a pathologic shift. To our knowledge, such pathologic shift in mollusk bivalve tissues has never been reported before.

Our results on stable isotope analyses evidenced that precaution must be taken if Manila clams are planned to be included in trophic food web studies. Only healthy individuals should be considered after a closer examination of their posterior muscles or, as a conservative alternative, only anterior adductor muscles should be sampled, when expertise in mollusk pathology is lacking. Finally, this work displayed the importance to acidify Manila clam tissues to remove inorganic carbonates in trophic web studies. 


\section{Acknowledgements}

We are particularly grateful to $E$. Lebraud from Institut de Chimie et de la Matière Condensée de Bordeaux to permit us to realize diffractometry analyses; to P. Lebleu, F. Prince for their assistance in the field; I. Billy, K. Charlier for technical assistance with elemental analyzer. The study was partly financed by ANR (Multistress project). C. Dang was supported by a grant from Fonds Commun de Coopération Aquitaine-Euskadi and Conseil Général de la Gironde. Thanks to R. B. Carnegie for discussion and English editing. The experiments comply with the current laws of the country in which the experiments were performed.

\section{References}

Dang C, de Montaudouin X, Gonzalez P, Mesmer-Dudons N, Caill-Milly N (2008) Brown muscle disease (BMD), an emergent pathology affecting Manila clam Ruditapes philippinarum in Arcachon Bay (SW France). Dis Aquat Org 80: 219-228. DOI 10.3354/dao01941

Dang C, Gonzalez P, Mesmer-Dudons N, Caill-Milly N, Bonami JR, De Montaudouin X (In press) Virus-like particles associated with brown muscle disease in Manila clam (Ruditapes philippinarum) in Arcachon Bay (France). J Fish Dis

DeNiro MJ, Epstein S (1978) Influence of diet on the distribution of carbon isotopes in animals. Geochim Cosmochim Acta 42: 495-506

DeNiro MJ, Epstein S (1981) Influence of diet on the distribution of nitrogen isotopes in animals. Geochim Cosmochim Acta 45: 341-351

Deudero S, Pinnegar JK, Polunin NVC (2002) Insights into fish host-parasite trophic relationships revealed by stable isotope analysis. Dis Aquat Org 52: 77-86. DOI 10.3354/dao052077

Flassch JP, Leborgne $Y$ (1992) Introduction in Europe, from 1972 to 1980, of the Japanese Manila clam (Tapes philippinarum) and the effects on aquaculture production and natural settlement. ICES Mar Sci symp 194: 92-96

Fry $B$, Sherr EB (1984) $d^{13} C$ measurements as indicators of carbon flow in marine and freshwater ecosystems. Contrib Mar Sci 27: 13-47

Goulletquer P, Heral M, Bechemin C, Richard P (1989) Anomalies de calcification chez la palourde japonaise Ruditapes philippinarum : caractérisation et comparaison des compositions en acides aminés de différentes parties de la coquille analysées par HPLC. Aquaculture 81: 169-183

Jing G, Yan Z, Li Y, Xie L, Zhang R (2007) Immunolocalization of an acid phosphatase from pearl oyster (Pinctada fucata) and its in vitro effects on calcium carbonate crystal formation. Mar Biotechnol 9: 650-659. DOI 10.1007/s10126-007-9018-0

Kanaya G, Nobata E, Toya T, Kikuchi E (2005) Effects of different feeding habits of three bivalve species on sediment characteristics and benthic diatom abundance. Mar Ecol Prog Ser 299: 67-78. DOI 10.3354/meps299067

Kasai A, Horie H, Sakamoto W (2004) Selection food sources by Ruditapes philippinarum and Mactra veneriformis (Bivalva: Mollusca) determined from stable isotope analysis. Fish Sci 70: 11-20. DOI 10.1111/j.1444-2906.2003.00764.x

Laruelle F, Guillou J, Paulet YM (1994) Reproductive pattern of the clams, Ruditapes decussatus and R. philippinarum on intertidal flats in Brittany. J Mar Biol Ass U K 74: 351366

Lassalle G, de Montaudouin X, Soudant P, Paillard C (2007) Parasite co-infection of two sympatric bivalves, the Manila clam (Ruditapes philippinarum) and the cockle 
(Cerastoderma edule) along a latitudinal gradient. Aquat Living Resour 20: 33-42. DOI 10.1051/alr: 2007013

Lorrain A, Paulet Y-M, Chauvaud L, Savoye N, Donval A, Saout C (2002) Differential $\delta^{13} C$ and $\delta^{15} \mathrm{~N}$ signatures among scallop tissues: implications for ecology and physiology. J Exp Mar Biol Ecol 275: 47-61. DOI 10.1016/S0022-0981 (02)00220-4

Machás R, Santos R, Peterson B (2003) Tracing the flow of organic matter from primary producers to filter feeders in Ria Formosa lagoon, southern Portugal. Estuaries 26: 846856. DOI 10.1007/BF02803343

Malet N, Sauriau P-G, Faury N, Soletchnik P, Guillou G (2007) Effect of seasonal variation in trophic conditions and the gametogenetic cycle on $\delta^{13} \mathrm{C}$ and $\delta^{15} \mathrm{~N}$ levels of diploid and triploid Pacific oysters Crassostrea gigas. Mar Ecol Prog Ser 346: 203-217. DOI 10.3354/meps06953

McCutchan JHJ, Lewis WMJ, Kendall C, McGrath CC (2003) Variation in trophic shift for stable isotope ratios of carbon, nitrogen, and sulfur. Oikos 102: 378-390. DOI 10.1034/j.1600-0706.2003.12098.x

Page HM, Lastra M (2003) Diet of intertidal bivalves in the Ría de Arosa (NW Spain): evidence from stable $\mathrm{C}$ and $\mathrm{N}$ isotope analysis. Mar Biol 143: 519-532. DOI 10.1007/s00227-003-1102-z

Paillard C (2004) A short review of brown ring disease, a vibriosis affecting clams, Ruditapes philippinarum and Ruditapes decussatus. Aquat Living Resour 17: 467-475. DOI 10.1051/alr: 2004053

Peterson BJ, Fry B (1987) Stable isotopes in ecosystem studies. Annu Rev Ecol Syst 18: 293-320

Sokal RR, Rohlf FJ (1981) Biometry. The principles and practice of statistics in biological research. Freeman, W.H. and Co., NJ

\section{Tables}

Table 1. Means ( \pm SE, $n=10$ ) of carbon and nitrogen stable isotope ratios (\%o) and $\mathrm{C} / \mathrm{N}$ content (mol.mol ${ }^{-1}$ ) of Ruditapes philippinarum adductor muscles before and after acidification. $\mathrm{H}$ : healthy, D: diseased, $\mathrm{P}$ : posterior, A: anterior.

\begin{tabular}{|c|c|c|c|c|c|c|}
\hline \multirow[b]{2}{*}{ Date } & \multirow[b]{2}{*}{ Status } & \multirow[b]{2}{*}{$\begin{array}{l}\text { Adductor } \\
\text { muscle }\end{array}$} & \multicolumn{3}{|c|}{ Before acidification } & \multirow{2}{*}{$\begin{array}{l}\begin{array}{l}\text { After } \\
\text { acidification }\end{array} \\
\delta{ }^{13} \mathrm{C}\end{array}$} \\
\hline & & & $\delta^{15} \mathrm{~N}$ & $\delta{ }^{13} \mathrm{C}$ & $\mathrm{C} / \mathrm{N}$ & \\
\hline \multirow{2}{*}{$\begin{array}{l}\text { Februar } \\
\text { y }\end{array}$} & $\mathrm{H}$ & $P$ & $9.2( \pm 0.11)$ & $-16.82( \pm 0.13)$ & $3.94( \pm 0.02)$ & $-16.85( \pm 0.13)$ \\
\hline & $\mathrm{D}$ & $\mathrm{P}$ & $8.9( \pm 0.13)$ & $-15.62( \pm 0.23)$ & $4.44( \pm 0.16)$ & $-16.43( \pm 0.12)$ \\
\hline \multirow{4}{*}{ August } & \multirow{2}{*}{$\mathrm{H}$} & A & $8.9( \pm 0.15)$ & $-17.49( \pm 0.07)$ & $3.68( \pm 0.02)$ & $-17.60( \pm 0.08)$ \\
\hline & & $P$ & $8.55( \pm 0.06)$ & $-17.57( \pm 0.06)$ & $3.70( \pm 0.02)$ & $-17.53( \pm 0.07)$ \\
\hline & \multirow{2}{*}{ D } & A & $9.10( \pm 0.14)$ & $-17.60( \pm 0.09)$ & $3.85( \pm 0.02)$ & $-17.40( \pm 0.09)$ \\
\hline & & $\mathrm{P}$ & $8.13( \pm 0.07)$ & $-16.80( \pm 0.25)$ & $4.59( \pm 0.07)$ & $-17.89( \pm 0.11)$ \\
\hline
\end{tabular}


Figures

Fig. 1.
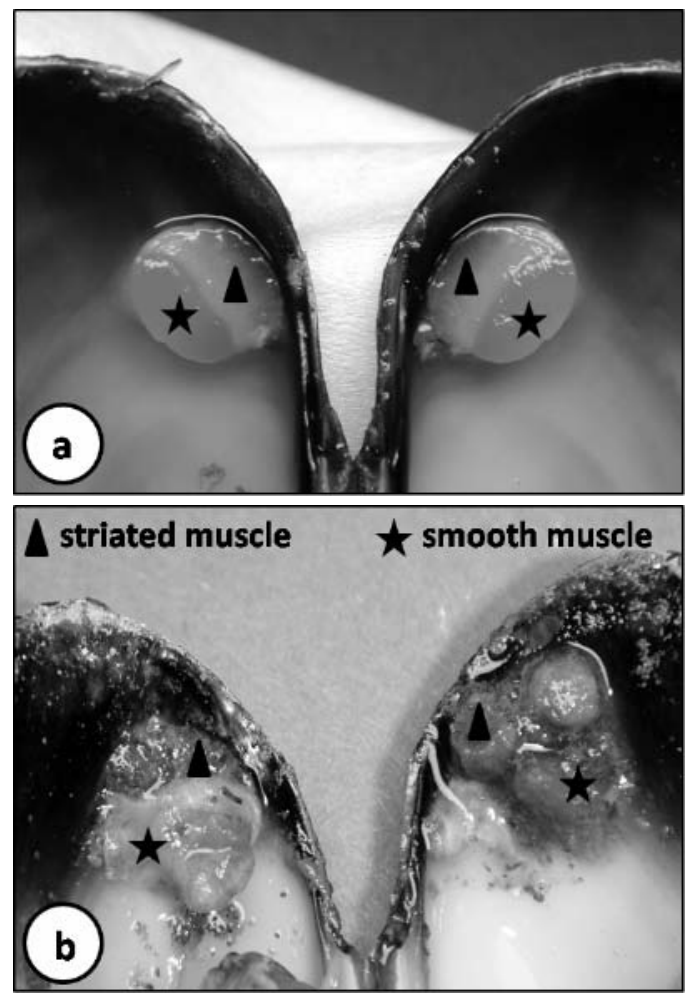

Fig. 1 Naked-eye observations of healthy $(F D I=0)(a)$ and diseased $(F D I=d)(b)$ posterior adductor muscle (striated and smooth muscles) of Ruditapes philippinarum. 
Fig. 2.

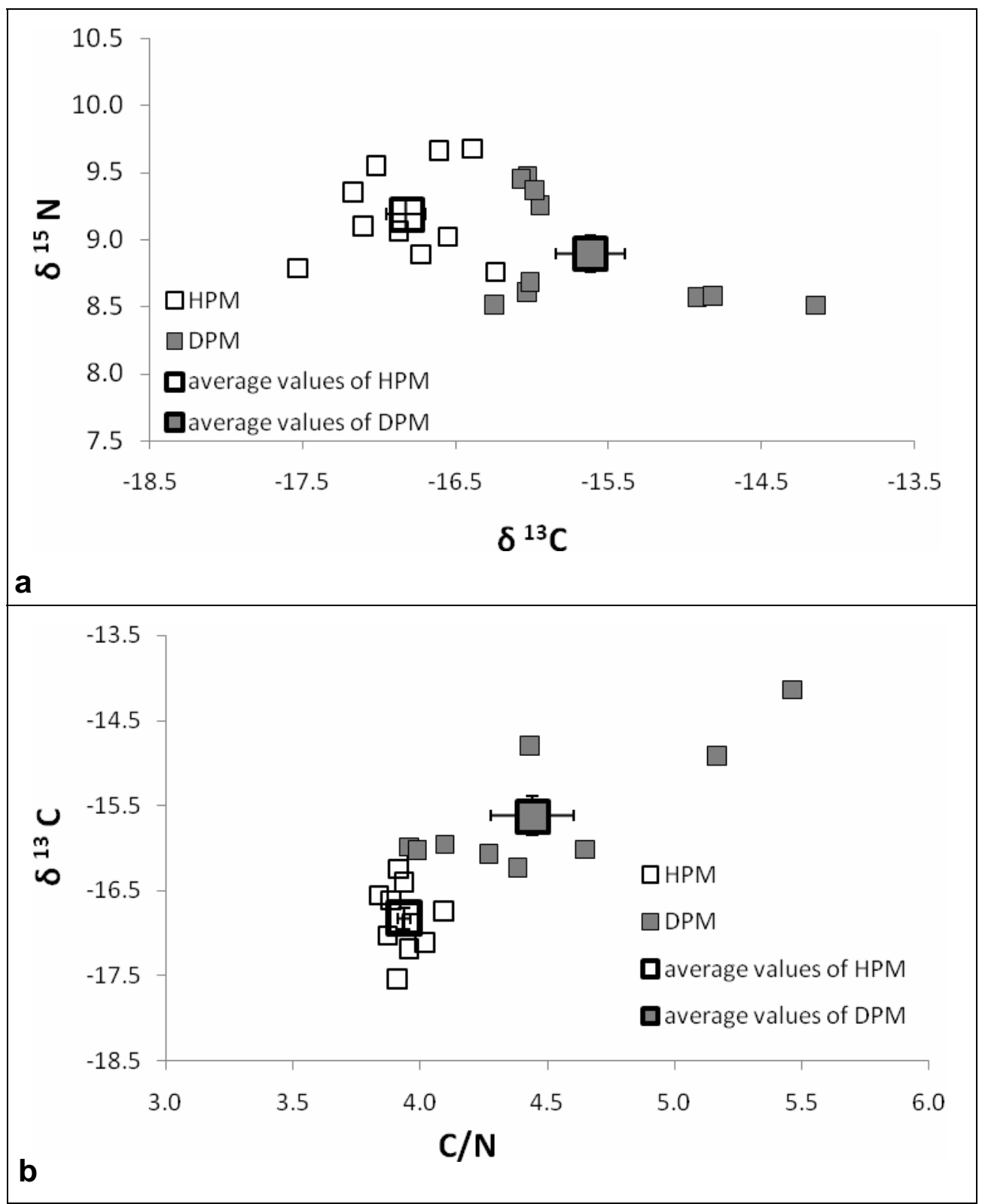

Fig. 2 Dual plots of nitrogen vs carbon stable isotope ratios (a) and carbon stable isotope ratio vs $\mathrm{C} / \mathrm{N}$ ratio (b) in posterior adductor muscles of Ruditapes philippinarum in February 2007. HPM, healthy posterior muscle. DPM, diseased posterior muscle. Averages are represented \pm standard error. 
Fig. 3.

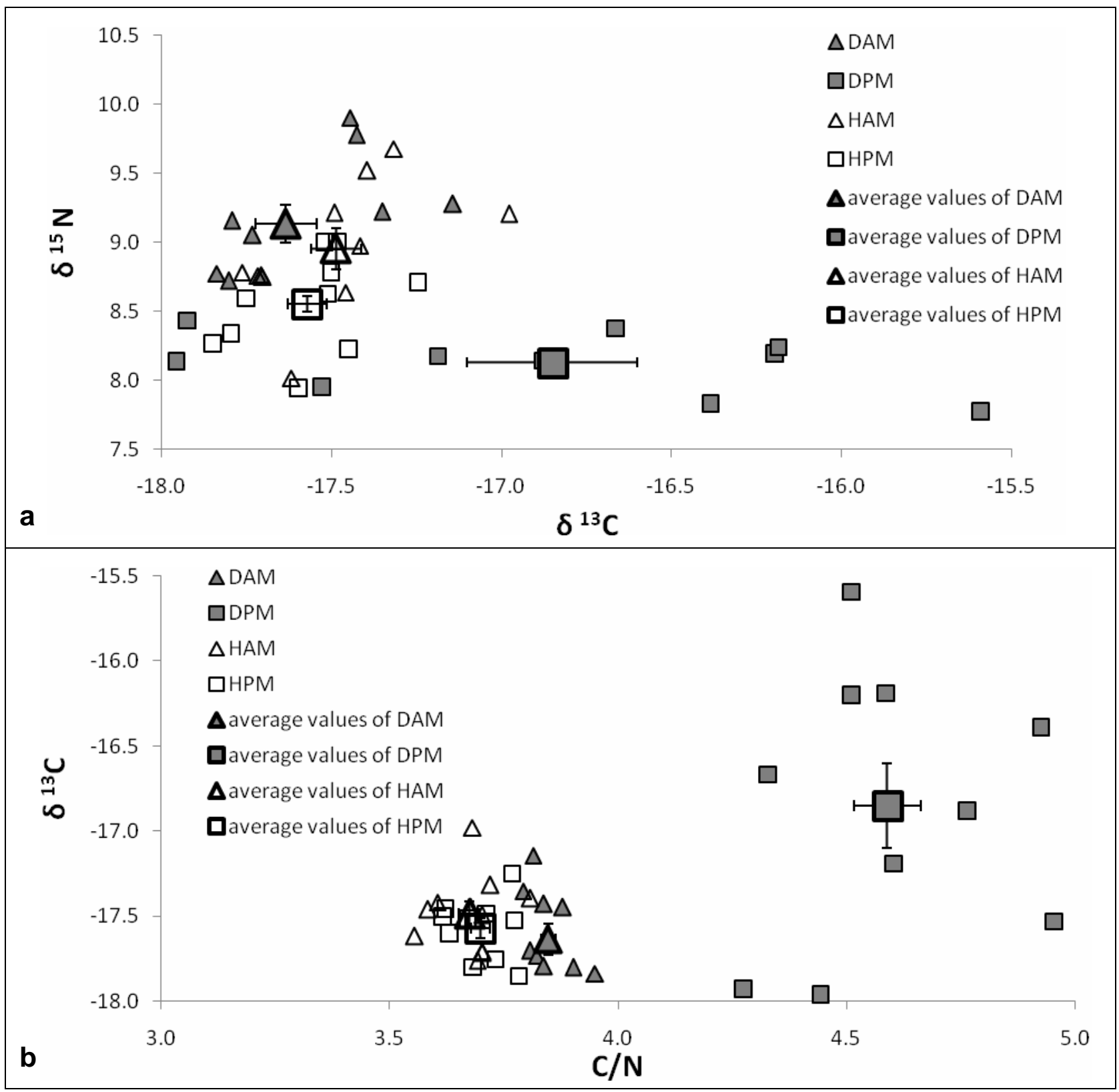

Fig. 3 Dual plots of nitrogen vs carbon stable isotope ratios (a) and stable carbon isotope ratio vs C/N ratio (b) in anterior and posterior adductor muscles of Ruditapes philippinarum gathered in August 2007. HPM, healthy posterior muscle. DPM, diseased posterior muscle. HAM, healthy anterior muscle. DAM, diseased anterior muscle. Averages are represented \pm standard error. 
Fig. 4.

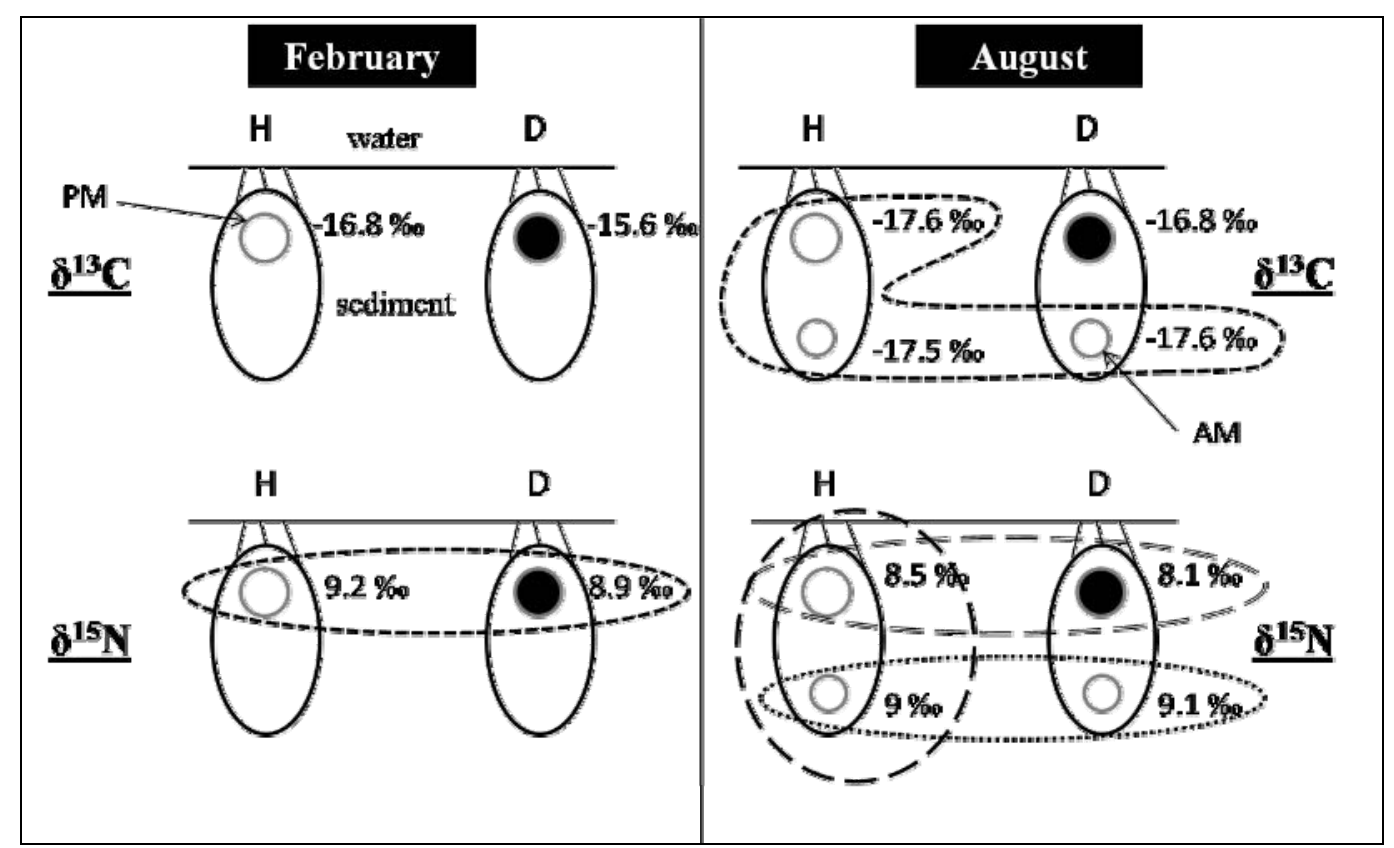

Fig. $4 \delta^{13} \mathrm{C}$ and $\delta^{15} \mathrm{~N}$ averages of healthy $(\mathrm{H})$ and diseased (D) clams in February and August 2007. Dotted lines gathered values that were not significantly different (Anova, Tukey test $p$ > 0.05). AM: anterior muscle; PM: posterior muscle. 
Fig. 5.

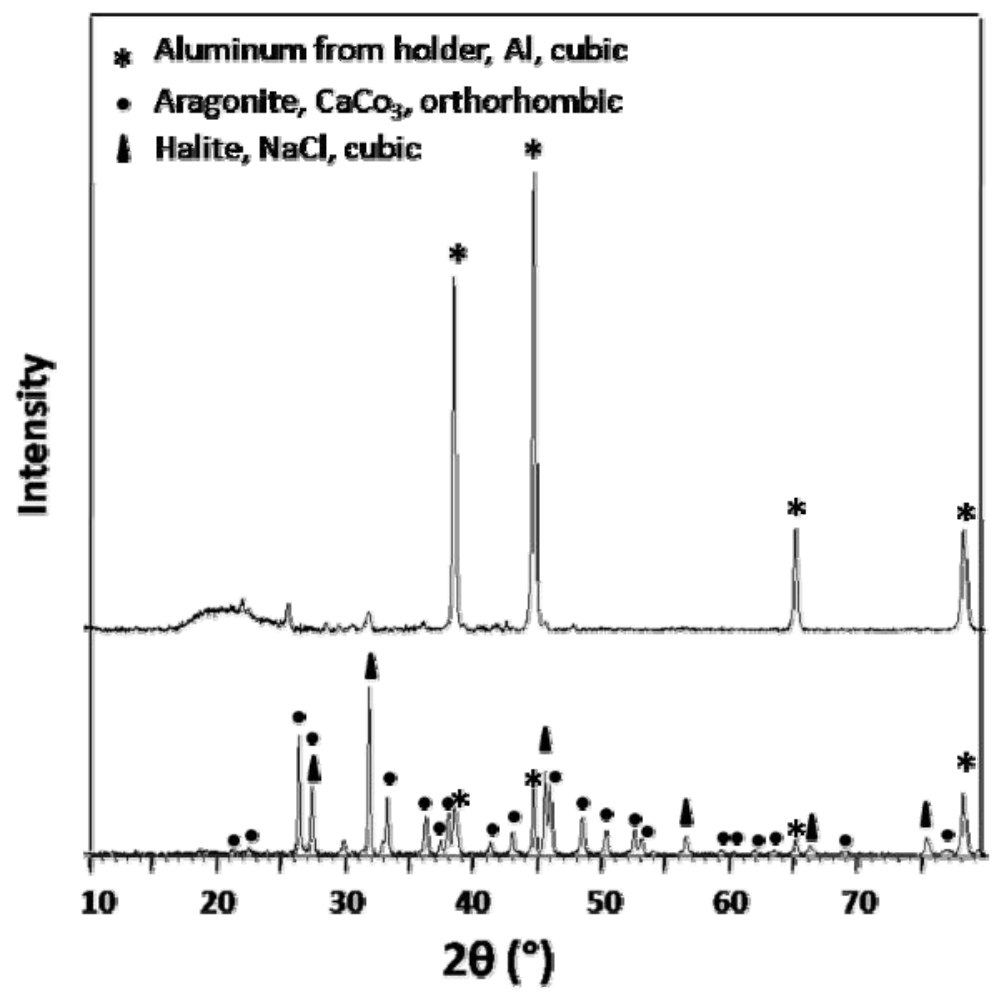

Fig. 5 X-ray diffraction patterns of healthy (above) and diseased (below) muscles. 